\title{
Aluminium hydrogensulfate as an efficient and heterogeneous catalyst for preparation of aryl $14 H$-dibenzo $[a, j]$ xanthene derivatives under thermal and solvent-free conditions
}

\author{
Hamid Reza Shaterian*, Majid Ghashang, and Nooshin Mir \\ Department of Chemistry, Faculty of Sciences, University of Sistan and Baluchestan, PO Box \\ 98135-674, Zahedan, Iran \\ E-mail:hrshaterian@hamoon.usb.ac.ir
}

\begin{abstract}
A new, one-pot, simple thermally efficient and solvent-free method for the preparation of aryl 14H-dibenzo[a,j]xanthene derivatives by condensation of $\beta$-naphthol and substituted benzaldehydes using aluminium hydrogensulfate $\mathrm{Al}\left(\mathrm{HSO}_{4}\right)_{3}$ as an inexpensive heterogeneous and reusable catalyst is described. This method has the advantages of high yields, a cleaner reaction, simple methodology, short reaction times, ambient pressure, easy workup and greener conditions.
\end{abstract}

Keywords: Aluminium hydrogensulfate, heterogeneous catalyst, dibenzoxanthene, solvent-free, $\beta$-naphthol, aldehyde

\section{Introduction}

Solid-phase organic synthesis (SPOS) has become increasingly important in synthesizing large numbers of combinatorial and parallel compound collections. ${ }^{1-5}$ The development of simple and eco-friendly synthetic procedures constitutes an important goal in organic synthesis. The use of inorganic solid supports such as clay, zeolite, alumina, silica gel for the generation of small organic molecules under solvent-free conditions has gained immense popularity because of its ease of set-up, mild conditions, increased yields of products, cost efficiency and environment friendliness compared to their homogeneous counterparts. ${ }^{6}$ As a part of our program to develop green synthetic procedures through surface-mediated solid phase reaction initiated a decade ago, ${ }^{7}$ we report here an efficient synthesis of $14 H$-dibenzo[ $a, j]$ xanthene derivatives by a simple reaction of condensation of $\beta$-naphthol and substituted benzaldehydes using aluminium hydrogensulfate under thermal conditions (Scheme 1). 
The synthesis of xanthenes, especially benzoxanthenes, has attracted the attention of organic chemists due to their wide range of biological and therapeutic properties such as antibacterial, ${ }^{8}$ antiviral activities, ${ }^{9}$ and also as a candidate in photodynamic therapy (PDT). ${ }^{10,11}$ PDT is a method of treating tumours by combined use of a photosensitizer and light. In this method, photosensitizers are injected directly into malignant tissue and by using the specific wavelength light excites the photosensitizer drug, this causes killing the tumour cells. ${ }^{10,11}$ Furthermore, benzoxanthenes are used as dyes, ${ }^{12}$ in laser technologies, ${ }^{13}$ and in fluorescent materials. ${ }^{14}$

The synthesis of $14 \mathrm{H}$-dibenzo[a,j]xanthene is generally achieved by a) dehydration of bis(2hydroxy-1-naphthyl ) methane using $\mathrm{POCl}_{3}{ }^{15}$ or by boiling acetic acid diester of bis(2-hydroxy1-naphthyl) methane; ${ }^{16}$ b) condensation of $\beta$-naphthol with aliphatic and aromatic aldehydes in the presence of hydrochloric acid or phosphoric acid ${ }^{17}$ and also sulfuric acid ${ }^{18}$ in acetic acid as solvent. All these methods suffer from harsh reaction conditions, long reaction times, unsatisfactory yields and tedious experimental procedures. Recently, the synthesis of $14 \mathrm{H}-$ dibenzo[a,j]xanthene has been reported by condensation of $\beta$-naphthol and aldehydes in the presence of $p$-toluenesulfonic acid, ${ }^{19,20}$ Selectfluor $^{\mathrm{TM}},{ }^{21}$ molecular iodine, ${ }^{22}$ sulfamic acid ${ }^{23}$ silica sulfuric acid, ${ }^{24}$ Amberlyst- $15^{25}$ and cation-exchange resins ${ }^{26}$ as catalyst.

Now, we report a one-pot synthesis of aryl $14 H$-dibenzo[ $a, j]$ xanthene derivatives by the reaction of various aromatic aldehydes with $\beta$-naphthol under solvent-free conditions in the presence of $\mathrm{Al}\left(\mathrm{HSO}_{4}\right)_{3}$ as a catalyst under thermal conditions. Aluminium hydrogensulfate has been used in some organic reaction, such as conversion of secondary amines to N-Nitroso compounds, ${ }^{27}$ silylation of alcohols, ${ }^{28}$ tetrahydropyranylation of alcohols, ${ }^{28}$ oxidation of alcohols, $^{29}$ acetalization of carbonyl compounds ${ }^{30}$ and Friedel-Crafts acylation of alkoxybenzenes. $^{31}$

In the present research, we wish to describe a new protocol for the rapid preparation of $14 \mathrm{H}$ dibenzo[a,j]xanthene derivatives using a catalytic amount of $\mathrm{Al}\left(\mathrm{HSO}_{4}\right)_{3}$ as a solid acid catalyst (Scheme 1). This catalyst is safe, easy to handle, environmentally benign and presents fewer disposal problems. Aluminium hydrogensulfate as a solid acid catalyst was prepared from the reaction of sulfuric acid with dry $\mathrm{AlCl}_{3}{ }^{31}$
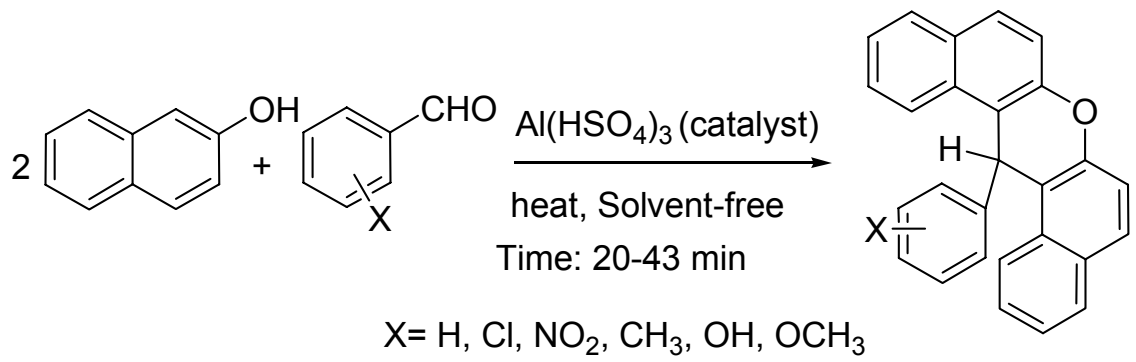

\section{Scheme 1}




\section{Results and Discussion}

As summarized in Table 1, several different aromatic aldehydes and $\beta$-naphthol were reacted in the presence of aluminium hydrogensulfate as catalyst under thermal and solvent-free conditions resulting in the corresponding aryl $14 H$-dibenzo $[a, j]$ xanthene in good to high yields (Scheme 1 and Table 1). The reaction was performed with benzaldehyde containing withdrawing as well as electron donating groups, but benzaldehydes with electron donating groups are generally more reactive than their corresponding benzaldehydes with electron withdrawing groups and give the desired product at short reaction time with excellent yield (Table 1). This observation shows clearly that the preparation of benzoxanthenes is more strongly affected by the electronic factors. The condensation reaction of ketones with $\beta$-naphthol was not occurred such reported in the literature.

The suggested mechanism of the aluminium hydrogensulfate catalyzed transformation is shown in Scheme 2.

In a typical experiment, after the reaction was completed, hot ethanol was added until solid crude product was dissolved. Then, the aluminium hydrogensulfate as catalyst was isolated from the mixture of the reaction by simple filtration and could be reused again after washing with hot ethanol. Recovered catalyst showed the same activity as fresh catalyst. In continuation of work up, the filtrate ethanol solution was concentrated. The aqueous ethanol $15 \%$ was added to the crude product, the precipitate was separated and then recrystallized using aqueous ethanol $15 \%$ for two times.

To show the merit of the present work in comparison with reported results in the literature, we compared results of aluminium hydrogensulfate with toluenesulfonic acid, ${ }^{19}$ iodine $^{22}$ and sulfamic $\operatorname{acid}^{23}$ in the synthesis of aryl $14 H$-dibenzo[a,j]xanthene derivatives. As shown in Table 2 , aluminium hydrogensulfate can act as effective catalyst with respect to reaction kinetic. 
Table 1. Synthesis of aryl $14 H$-dibenzo[a,j]xanthene derivatives in presence of $\mathrm{Al}\left(\mathrm{HSO}_{4}\right)_{3}$ as catalyst from $\beta$-naphthol and aromatic aldehydes under thermal and solvent-free conditions

\begin{tabular}{|c|c|c|c|c|c|}
\hline Entry & Aldehydes & Time(min) & Yield $^{\mathrm{a}}(\%)$ & $\begin{array}{c}\text { m.p }\left({ }^{\circ} \mathrm{C}\right)[\text { Lit.M.p. } \\
\text { ] }\end{array}$ & $\begin{array}{l}\text { References to the } \\
\text { known product }\end{array}$ \\
\hline 1 & & 31 & $\begin{array}{l}90(87- \\
90)^{\mathrm{b}}\end{array}$ & $182(183)$ & $18-24$ \\
\hline 2 & & 37 & 87 & $228(227)$ & 24 \\
\hline 3 & & 29 & 90 & $288(287)$ & $19-24$ \\
\hline 4 & & 31 & 91 & $173(174)$ & 24 \\
\hline 5 & & 43 & 90 & $315(312)$ & $18,19,21-24$ \\
\hline 6 & & 39 & 91 & $214(213)$ & $19,21-24$ \\
\hline 7 & & 20 & 85 & $141(140)$ & $21,22,24$ \\
\hline 8 & & 27 & 87 & 169 (167) & 24 \\
\hline 9 & & 27 & 89 & 227 (228) & $18-24$ \\
\hline 10 & & 23 & 89 & $169(168)$ & 24 \\
\hline
\end{tabular}

${ }^{a}$ Yields refer to pure isolated products. All known products have been reported previously in the literature and were characterized by comparison of IR and NMR spectra with authentic samples. ${ }^{18-24}$

${ }^{\mathrm{b}}$ Yields after five times of catalyst recovery. 


\section{Mechanism}
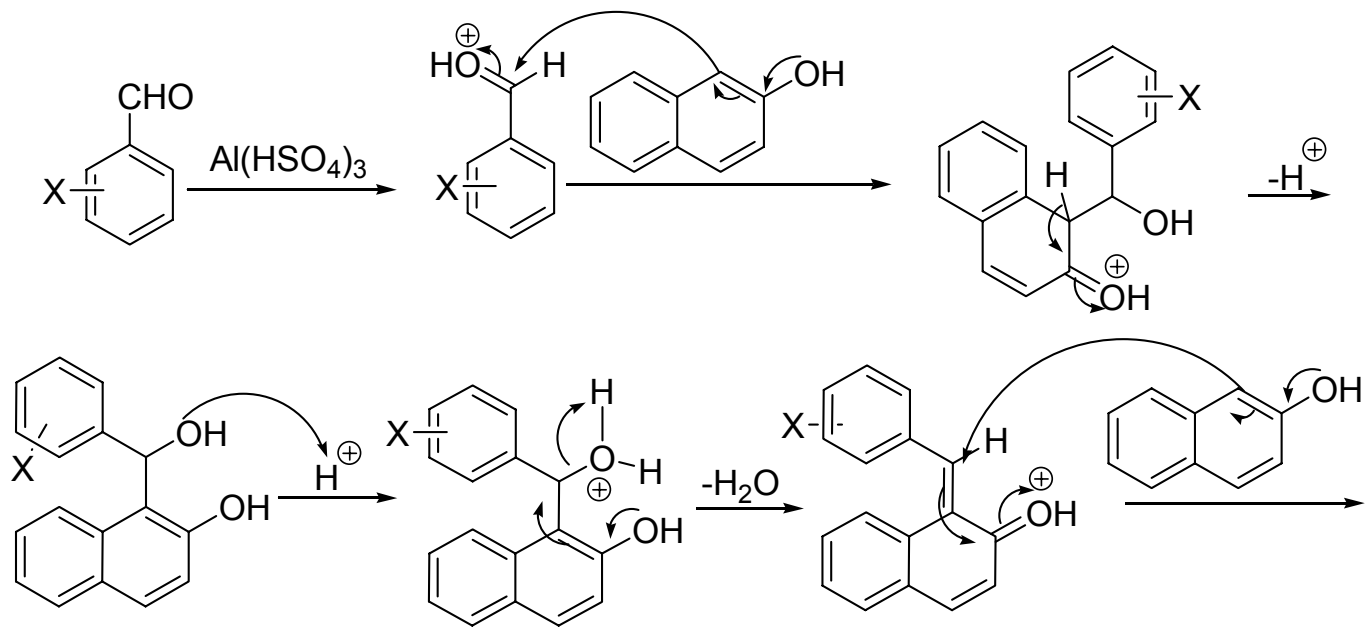<smiles>[Y]c1ccc(C2c3c(ccc4ccccc34)OC3(O)C=Cc4ccccc4C3C2c2ccccc2C=CC(C)C)cc1</smiles>

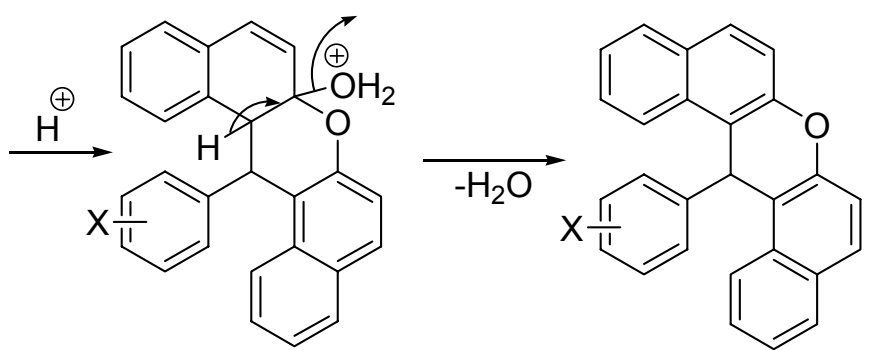

\section{Scheme 2}


Table 2. Comparison result of aluminium hydrogensulfate ${ }^{31}$ with toluenesulfonic acid, ${ }^{19}$ iodine 22 and sulfamic acid ${ }^{23}$ in the synthesis of dibenzoxanthene

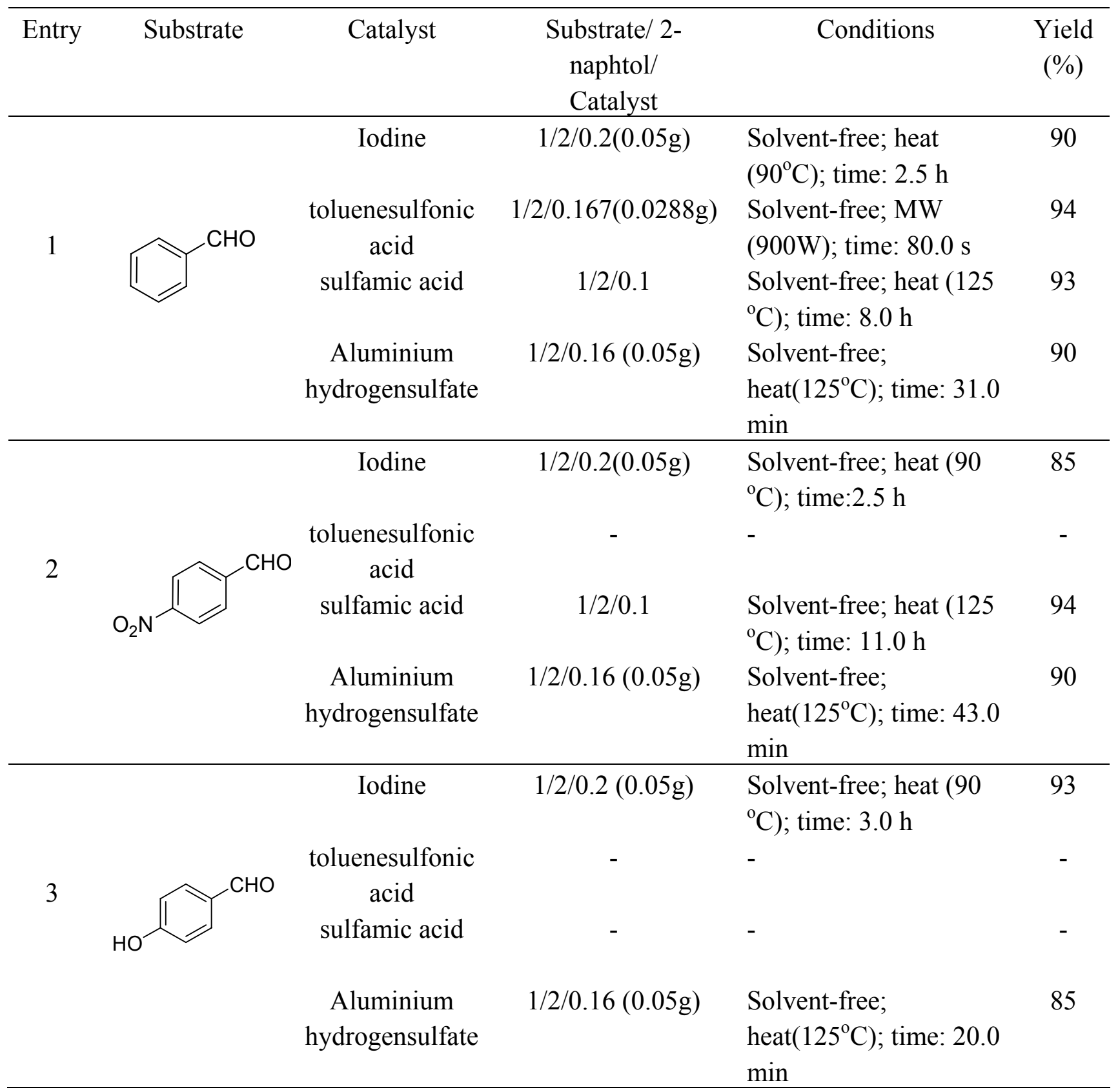

In conclusion, we have demonstrated that aluminium hydrogensulfate is a new, efficient, heterogeneous, cheapness and available catalyst for synthesis of a variety of aryl $14 \mathrm{H}-$ dibenzo[a,j]xanthene derivatives using aryl aldehydes and $\beta$-naphthol under solvent-free conditions. The reactions were carried out at oil bath with short reaction time and produce the corresponding product in good to high yields. This method is important from an environmental point of view and economic considerations, because it produces little waste. Greener conditions 
and simple work-up procedure, including filtering and recrystallization, catalyst recovery and also reusability are another advantage of this method.

\section{Experimental Section}

General Procedures. All reagents were purchased from Merck and Aldrich and used without further purification. $\mathrm{Al}\left(\mathrm{HSO}_{4}\right)_{3}$ was prepared according to the reported procedure. ${ }^{[31]}$ All yields refer to isolated products after purification. Products were characterized by comparison with authentic samples and by spectroscopy data (IR, ${ }^{1} \mathrm{H}$ NMR spectra) and melting point. The NMR spectra were recorded on a Bruker Avance DPX 500 and $300 \mathrm{MHz}$ instrument. The spectra were measured in $\mathrm{CDCl}_{3}$ relative to TMS $(0.00 \mathrm{ppm})$. IR spectra were recorded on a Perkin-Elmer 781 spectrophotometer. All of the compounds were solid and solid state IR spectra were recorded using the $\mathrm{KBr}$ disk technique. Melting points were determined in open capillaries with a BUCHI 510 melting point apparatus and are uncorrected. TLC was performed on Silica-gel polygram SIL G/UV 254 plates.

\section{Preparation of aluminium hydrogensulfate}

A $500 \mathrm{~mL}$ suction flask was equipped with a constant-pressure dropping funnel. The gas outlet was connected to a vacuum system through an adsorbing solution (water) and an alkali trap. Anhydrous aluminium chloride $(33.4 \mathrm{~g}, 0.25 \mathrm{~mol})$ was charged in the flask and concentrated sulfuric acid $(98 \%, 73.5 \mathrm{~g}, 0.75 \mathrm{~mol})$ was added dropwise over a period of $30 \mathrm{~min}$ at room temperature during which $\mathrm{HCl}$ was evolved immediately. After completion of the addition, the mixture was shaken for $30 \mathrm{~min}$, while the residual $\mathrm{HCl}$ was eliminated by suction. Finally, a pale-brown solid material was obtained in $77 \mathrm{~g}$ was characterized according to the previously reported procedure. ${ }^{31}$

\section{General procedure for preparation of $14 H$-dibenzo[a,j]xanthene derivatives using aluminum hydrogensulfate as catalyst}

To a mixture of aldehyde $(1 \mathrm{mmol})$ and $\beta$-naphthol $(2 \mathrm{mmol})$, aluminium hydrogensulfate $(0.16$ mmol, $0.05 \mathrm{~g}$ ) was added and the mixture was inserted in inserted in an oil bath and heated at $125^{\circ} \mathrm{C}$ for the appropriate time (Table 1). Completion of the reaction was indicated by TLC. After the reaction was completed, ethanol was added and the reaction mixture was heated until solid crude product was dissolved. Then, the heterogeneous catalyst was isolated from the mixture of the reaction by simple filtration. In continuation of work up, the filtrate ethanol solution was concentrated. The aqueous ethanol 15\% was added to the crude product, the precipitate was separated and then recrystallized using aqueous ethanol $15 \%$ for two times. The desired pure product(s) was characterized by comparison of their physical data with those of known benzoxanthenes. The spectral data of some representative aryl 14H-dibenzo[a,j]xanthenes are given below: 
(X=2,4-Dichloro in scheme 1, Table 1, Entry 2). ${ }^{1} \mathrm{H}$ NMR $\left(\mathrm{CDCl}_{3}, 500 \mathrm{MHz}\right): \delta=8.65$ (2H, d, $J=8.5 \mathrm{~Hz}), 7.83(2 \mathrm{H}, \mathrm{d}, J=7.9 \mathrm{~Hz}), 7.80(2 \mathrm{H}, \mathrm{d}, J=8.8 \mathrm{~Hz}), 7.63(2 \mathrm{H}, \mathrm{t}, J=7.5 \mathrm{~Hz}), 7.48(2 \mathrm{H}$, $\mathrm{d}, J=8.8 \mathrm{~Hz}), 7.45(2 \mathrm{H}, \mathrm{t}, J=7.4 \mathrm{~Hz}), 7.31(1 \mathrm{H}, \mathrm{d}, J=8.6 \mathrm{~Hz}), 7.27(1 \mathrm{H}, \mathrm{s}), 6.88(1 \mathrm{H}, \mathrm{d}, J=$ $6.8 \mathrm{~Hz}), 6.75(1 \mathrm{H}, \mathrm{s}) \mathrm{ppm} ;{ }^{13} \mathrm{C}$ NMR $\left(\mathrm{CDCl}_{3}\right): \delta=148.9,142.2,132.8,132.6,131.6,130.9$, 130.6, 129.3, 129.1, 128.7, 128.4, 127.0, 124.5, 123.1, 118.0, 117.4, $34.3 \mathrm{ppm}$; IR (KBr, $\left.\mathrm{cm}^{-1}\right)$ : $3057,2920,1619,1592,1558,1514,1458,1404,1240,1208,1141,1101,1041,960,863,836$, $808,742,699,607$.

(X=3-Chloro in Scheme 1, Table 1, Entry 4). ${ }^{1} \mathrm{H}$ NMR $\left(\mathrm{CDCl}_{3}, 300 \mathrm{MHz}\right): \delta=8.33(2 \mathrm{H}, \mathrm{d}, J=$ $8.4 \mathrm{~Hz}), 7.84(2 \mathrm{H}, \mathrm{d}, J=8.6 \mathrm{~Hz}), 7.80(2 \mathrm{H}, \mathrm{d}, J=9.0 \mathrm{~Hz}), 7.61(2 \mathrm{H}, \mathrm{t}, J=7.0 \mathrm{~Hz}), 7.49(2 \mathrm{H}, \mathrm{d}, J$ $=8.9 \mathrm{~Hz}), 7.47-7.41(4 \mathrm{H}, \mathrm{m}), 7.09(1 \mathrm{H}, \mathrm{t}, J=8.0 \mathrm{~Hz}), 6.98(1 \mathrm{H}, \mathrm{d}, J=8.7 \mathrm{~Hz}), 6.45(1 \mathrm{H}, \mathrm{s})$ ppm; ${ }^{13} \mathrm{C} \mathrm{NMR}\left(\mathrm{CDCl}_{3}\right): \delta=148.7,146.9,134.4,131.2,131.0,129.6,129.1,128.9,128.3,126.9$, 126.7, 126.4, 124.4, 122.4, 118.0, 116.5, 37.7 ppm; IR (KBr, $\left.\mathrm{cm}^{-1}\right): 2922,1621,1590,1509$, 1456, 1431, 1397, 1245, 1065, 959, 812, 775, 746, 691.

(X=4-Hydroxy-2methoxy in Scheme 1, Table 1, Entry 8). ${ }^{1} \mathrm{H}$ NMR $\left(\mathrm{CDCl}_{3}, 500 \mathrm{MHz}\right): \delta=$ $8.40(2 \mathrm{H}, \mathrm{d}, J=8.2 \mathrm{~Hz}), 7.83(2 \mathrm{H}, \mathrm{d}, J=7.8 \mathrm{~Hz}), 7.79(2 \mathrm{H}, \mathrm{d}, J=8.7 \mathrm{~Hz}), 7.58(2 \mathrm{H}, \mathrm{t}, J=7.2$ $\mathrm{Hz}), 7.48(2 \mathrm{H}, \mathrm{d}, J=8.7 \mathrm{~Hz}), 7.42(2 \mathrm{H}, \mathrm{t}, J=7.2 \mathrm{~Hz}), 7.15(1 \mathrm{H}, \mathrm{d}, J=8.0 \mathrm{~Hz}), 6.85(1 \mathrm{H}, \mathrm{s})$, $6.73(1 \mathrm{H}, \mathrm{d}, J=8.0 \mathrm{~Hz}), 6.44(1 \mathrm{H}, \mathrm{s}), 5.34(1 \mathrm{H}, \mathrm{s}), 3.65(3 \mathrm{H}, \mathrm{s}) \mathrm{ppm} ;{ }^{13} \mathrm{C} \mathrm{NMR}\left(\mathrm{CDCl}_{3}\right): \delta=$ 148.7, 146.7, 144.1, 137.1, 131.4, 131.1, 128.8, 128.7, 126.7, 124.2, 122.7, 121.0, 117.9, 117.5, 113.7,110.7, 55.6, 37.5 ppm; IR (KBr, $\left.\mathrm{cm}^{-1}\right): 3477,2963,1591,1509,1458,1430,1401,1240$, $1032,959,805,781,749$.

( $\mathbf{X}=\mathbf{2 , 5 - D i m e t h o x y ~ i n ~ S c h e m e ~ 1 , ~ T a b l e ~ 1 , ~ E n t r y ~ 1 0 ) . ~}{ }^{1} \mathrm{H}$ NMR $\left(\mathrm{CDCl}_{3}, 300 \mathrm{MHz}\right): \delta=8.62$ $(2 \mathrm{H}, \mathrm{d}, J=8.4 \mathrm{~Hz}), 7.82(2 \mathrm{H}, \mathrm{d}, J=8.0 \mathrm{~Hz}), 7.78(2 \mathrm{H}, \mathrm{d}, J=8.9 \mathrm{~Hz}), 7.59(2 \mathrm{H}, \mathrm{t}, J=7.3 \mathrm{~Hz})$, $7.50(2 \mathrm{H}, \mathrm{d}, J=8.8 \mathrm{~Hz}), 7.45(2 \mathrm{H}, \mathrm{t}, J=7.4 \mathrm{~Hz}), 6.9(1 \mathrm{H}, \mathrm{s}), 6.84(1 \mathrm{H}, \mathrm{s}), 6.78(1 \mathrm{H}, \mathrm{d}, J=9.0$ $\mathrm{Hz}), 6.48(1 \mathrm{H}, \mathrm{d}, J=6.0 \mathrm{~Hz}), 4.24(3 \mathrm{H}, \mathrm{s}), 3.47(3 \mathrm{H}, \mathrm{s}) \mathrm{ppm} ;{ }^{13} \mathrm{C} \mathrm{NMR}\left(\mathrm{CDCl}_{3}\right): \delta=154.1$, 148.8, 148.2, 135.6, 132.0, 129.9, 129.7, 128.6, 128.5, 126.7, 124.2, 123.4, 118.3, 117.0, 111.9, ,111.3, 56.1, 55.2, 30.5 ppm; IR (KBr, $\left.\mathrm{cm}^{-1}\right): 2925,2831,1622,1594,1496,1461,1430,1407$, $1256,1207,1173,1043,965,849,813,800,746,702$. 


\section{Acknowledgements}

We are thankful to the Sistan and Baluchestan University Research Council for the partial support of this research.

\section{References}

1. Bannwarth, W.; Hinzen. B. Combinatorial Chemistry: From Theory to Application Wiley/VCH: Weinheim, Germany, 2006.

2. Dolle, R. E.; Jr. Nelson, K. H. J. Comb. Chem. 1999, 1, 235.

3. Dolle, R. E. J. Comb. Chem. 2000, 2, 383.

4. Ding, S.; Gray, N. S.; Wu, X.; Ding, Q.; Schultz, P. G. J. Am. Chem. Soc. 2002, 124, 1594.

5. Lowrie, J. F.; DeLisle, R. K.; Hobbs, D. W.; Diller, D. J. Comb. Chem. High Throughput Screening 2004, 7, 495.

6. (a)Balogh, M.; Laszlo, P. Organic Chemistry Using Clays; Springer-Verlag: Berlin, 1993. (b) Kabalka, G.; Pagni, R. M. Tetrahedron 1997, 53, 7999. (c) McKillop, A.; Young, D.W. Synthesis 1979, 401. (d) Laszlo, P. Ed. Preparative Chemistry Using Supported Reagents; Academic Press: San Diego, 1987. (e) Smith, K.; Ed. Solid Supports and Catalysts in Organic Synthesis; Ellis Horwood: Chichester, 1992. (f) Clark, J. H.; Kybett, A.P.; Macquarrie, D. J., Supported Reagents - Preparation, Analysis and Applications; VCH: Weinheim, 1992.

7. Ranu, B. C.; Sarkar, D. C. Tetrahedron Lett. 1991, 32, 2811. (b) Ranu, B. C.; Bhar, S. J. Chem. Soc., Perkin Trans. 1 1992, 365. (c) Ranu, B. C.; Chakraborty, R. Synth. Commun. 1992, 22, 1095. (d) Ranu, B. C.; Bhar, S.; Chakraborti, R. J. Org. Chem. 1992, 57, 7349. (e)Ranu, B. C.; Saha, M.; Bhar, S. Tetrahedron Lett. 1993, 34, 1989. (f) Ranu, B. C.; Chakraborty, R. Tetrahedron 1993, 49, 5333. (g) Ranu, B. C.; Saha, M. J. Org. Chem. 1994, 59, 8269. (h) Ranu, B. C.; Ghosh, K.; Jana, U. J. Org. Chem. 1996, 61, 9546. (i) Ranu, B. C.; Jana, U.; Majee, A. Green Chemistry 1999, 33. (j) Ranu, B. C.; Hajra, A.; Jana, U. Tetrahedron Lett. 2000, 41, 531. (k) Ranu, B. C.; Hajra, A.; Jana, U. Synlett 2000, 75. (1) Ranu, B. C.; Hajra, A. Tetrahedron 2001, 57, 4767. (m) Ranu, B. C.; Samanta, S.; Hajra, A. Synlett 2002, 987. (n) Ranu, B. C.; Hajra, A.; Dey, S. S.; Jana, U. Tetrahedron 2003, 59, 813.

8. Hideo, T. Jpn. Tokkyo Koho, Chem. Abstr. 1981, 95, 80922b, JP 56005480.

9. Lambert, R. W.; Martin, J. A.; Merrett, J. H.; Parkes, K. E. B.; Thomas, G. J. Chem. Abstr. 1997, 126, p212377y.

10. Ion, R. M. Prog. Catal. 1997, 2, 55.

11. Ion, R. M.; Frackowiak, D.; Planner, A.; Wiktorowicz, K. Acta Biochim. Pol. 1998, 45, 833.

12. Banerjee, A.; Mukherjee, A. K. Stain Technol. 1981, 56, 83. 
13. Ahmad, M.; King, T. A.; Ko, Do-K.; Cha, B. H.; Lee, J. J. Phys. D: Appl. Phys. 2002, 35, 1473 .

14. Knight, C. G.; Stephens, T. Biochem. J. 1989, 258, 683.

15. Wolf, W. Chem. Ber. 1893, 26, 83.

16. Rosebush, I. K. Das Leder 1955, 6, 58.

17. Khorramabadi-zad, A.; Kazemi, Z.; Amini Rudbari, H. J. Kor. Chem. Soc. 2002, 46, 541.

18. Sarma, R. J.; Baruah, J. B. Dyes Pigm. 2005, 64, 91.

19. Khorramabadi-zad, A.; Akbari, S. A.; Shiri, A.; Veisi, H. J. Chem.Res. 2005, 277.

20. Khosropour, A. R.; Khodaei, M. M.; Moghannian, H. Synlett. 2005, 955.

21. Kumara, P. S.; Kumara, B. S.; Rajithaa, B.; a Reddya, P. N.; Sreenivasulua, N.; Reddy Y. T. Arkivoc 2006, 46.

22. Das, B.; Ravikanth, B.; Ramu, R.; Laxminarayana, K.; Vittal Rao, B. J. Mol. Catal. A: Chem. 2006, 255, 74.

23. Rajitha, B.; Sunil Kumar, B.; Thirupathi Reddy, Y.; Narsimha Reddy, P.; Sreenivasulu, N. Tetrahedron Lett. 2005, 46, 8691.

24. Shaterian, H. R.; Ghashang, M.; Hassankhani, A. Dyes Pigm. 2006, in press.

25. Ko, S.; Yao C.-F. Tetrahedron Lett. 2006, 47, 8827.

26. Patil, S. B.; Bhat, R. P.; Samant, S. D. Synthetic Commun. 2006, 36, 2163.

27. Zolfigol, M. A.; Ghorbani Choghamarani, A.; Taqian-Nasab, A.; Keypour, H.; Salehzadeh, S. Bull. Kor. Chem. Soc. 2003, 24, 638.

28. Shirini, F.; Zolfigol, M. A.; Abedini, M. Bull. Chem. Soc. Jpn. 2005, 78, 1982.

29. Shirini, F.; Zolfigol, M. A.; Abedinia, M.; Salehi, P. Mendeleev Commun. 2003, 265.

30. Mirjalili, B. F.; Zolfigol, M. A.; Bamoniri, A.; Hazar A. J. Braz. Chem. Soc. 2005, 16, 877.

31. Salehi, P.; Khodaei, M. M.; Zolfigol, M. A.; Sirouszadehy, S. Bull. Chem. Soc. Jpn. 2003, $76,1863$. 